\title{
Indexação regularizada no Google Acadêmico.
}

\author{
Éber Coelho Paraguassu (1)
}

\section{EDITORIAL}

Após quase um ano de probelmas com indexação no Google Acadêmico, informo a todos os autores e leitores do BJIHS que o periódico voltou a ter todos seus artigos indexados na plataforma e tudo esta de volta ao normal.

Este retorno só foi possivel graças a ação judicial impetrada por este jornal contra a Google, que reconhecendo o erro em juizo o corrigio.

Instituição afiliada: 1- Specialized dentistry Group

Dados da publicação: Artigo recebido em 21 de Maio, revisado em 22 de Maio, aceito para publicação em 25 de Maio e publicado em 30 de Maio..

DOI: https://doi.org/10.36557/2674-8169.2021v3n5p03-03

@ Éber Coelho Paraguassu dr.paraguassu@periodicosbrasil.com.br

This work is licensed under a Creative Commons Attribution 4.0 International

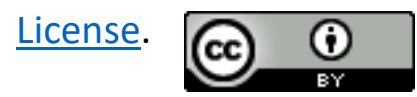

